UDC 346.14

DOI https://doi.org/10.32849/2663-5313/2021.10.02

Oksana Vinnyk,

Doctor of Law, Professor, Corresponding Member of the National Academy of Law Sciences of Ukraine, Chief Researcher, F. H. Burchak Scientific Research Institute of Private Law and Entrepreneurship of the National Academy of Law Sciences of Ukraine, 23a, Mykola Raevsky street, Kyiv, Ukraine, postal code 01042, ovinnyk@ukr.net

ORCID: orcid.org/0000-0002-9397-5127

Scopus-Author ID: 57217737384

Vinnyk, Oksana (2021). Ecological component in the economic and legal policy of the state. Entrepreneurship, Economy and Law, 10, 10-15, doi https://doi.org/10.32849/2663-5313/2021.10.02

\title{
ECOLOGICAL COMPONENT IN THE ECONOMIC AND LEGAL POLICY OF THE STATE
}

Abstract. Purpose. In the modern era of society, which is already called digital due to the widespread use of digital technologies, the environmental impact of the latter is ambiguous: in addition to the positive effect (an opportunity to address hyper-complex tasks), digitalization is also associated with significant risks. The article studies a range of digitalization-driven problems (from the perspective of its effect on the economy and ecology) with the purpose of developing legal means to mitigate the relevant risks.

Research methods. The use of scientific methods (dialectical, formal logic, systems approach, synthesis, synergetic approach, predictive method, etc.) allowed concluding about the need to make adjustments to the economic and legal policy of the state with a mandatory consideration of an ecological component.

Results. The conclusion about the need for legislative consideration of both positive and negative effects of digitalization relies on the analysis of the actual state of economic and environmental affairs, theoretical contributions of domestic and foreign authors, and the status of the statutory regulation of the mentioned relations. The study reveals the ambiguity of effects caused by digital technologies, the use of which may be sufficiently favorable for society but associated with significant risks. It refers to the use of digital technologies without paying attention to the ecological component (the so-called carbon footprint, which accelerates negative climate change), irrespective of other adverse effects.

Conclusions. The research outcome involves eliciting a complex of challenges related to the impact of digitalization on the economy and ecology, as well as their interrelation; the poor status of dealing with the challenges through legal means; proposals for improving the legal groundwork for guaranteeing the solution of the problems of a risk-laden impact of digitalization on the economy and ecology, namely, encompassing provisions on the state's social orientation of digitalization, which embraces the stimulation of the positive use of digital technologies and reduction of digitalization-driven risks by fundamental statutory acts, governing the relevant relations (the Constitution of Ukraine, Commercial Code of Ukraine, and the Law of Ukraine "On Environmental Protection").

Key words: economy, ecology, digitalization, risks of digitalization, improvement of legislation.

\section{Introduction.}

In today's highly troublesome society, which is called a threat / danger/ risk society (Beck Ulrich, 1992), there are high hopes for digitalization with its potential to solve major problems. The coronavirus pandemic and related quarantine restrictions have proven the benefits of digitalization: the ability to act remotely by addressing both household and business issues, use a set of health services (namely, the "Dii vdoma" app, online pharmacies and shopping, artificial intelligence, chatbots, robots, digital platforms, etc.) to fight against the disease and ensure economic performance in the context of restrictive quarantine measures (for patient care, the development of effective drugs and vaccines, remote ordering of goods/ works/services, conducting various events online, environmental monitoring, etc.). These are some examples of the positive effects of digitalization. However, like any other phenomenon in public life, the use of digital technologies has a downside, which is often not taken into account. At the initial stages of digitalization, it was proclaimed freedom and independence (primarily from state control) of cyberspace (A Declaration of the Independence of Cyberspace, 1996). The issue concerns the use of digital opportunities either for the benefit of society, economic and environmental spheres, etc. or vivid anti-social goals (cybercrime, e.g., massive cyber-attacks against government and business 
institutions or entire economic systems), or pursuing a thoughtless goal (without regard to the consequences, e.g., the online dissemination of fake information about the extreme harmfulness of COVID-19 vaccines), or for ignoring the impact on the environment, society, its economic sphere (cryptocurrency mining that requires a significant amount of electricity (Oberhaus D., 2018), which is mainly produced from non-renewable sources along with the aggravation of the so-called carbon footprint (Markevych Kateryna, 2021), and the generation of thermal energy, which often harms the environment, although there are technologies for its use for the public good).

The study is based on the contributions of Ukrainian and foreign scientists who brought up issues of digitalization in terms of the economy and environmental protection: the Center for Innovations Development studied the environmental realm (Analitychnyy zvit. 2021 ), K. Markevych - the carbon footprint of digitalization (Markevych Kateryna. 2021), M. Kinakh - the green course of Ukraine (Kinakh Marharyta. 2020), S. Romanko the role of digitalization in the environmental policy of Ukraine in terms of climate change (Romanko S. 2019). The impact of digitalization on economy and ecology was elucidated by the Razumkov Center developments (Razumkov Center, 2020), cybersecurity in space activities - Malysheva N.R. (Malysheva N.R. 2021), the digitalization of the economic sphere a group of authors (Oksana M. Vinnyk, Olga V. Shapovalova, Nino B. Patsuriia, Olena M. Honcharenko, Kateryna V. Yefremova. 2020; Oksana M. Vinnyk, Dmytro V. Zadykhaylo, Olena M. Honcharenko, Olga V. Shapovalova, Nino B. Patsuriia. 2021), and the legal regulation of relations on the Internet - a collective work (Hetman A. P., Atamanova Yu. Ye., Milash V. S., et al., 2016.). The issues of the ambiguous impact of digitalization on the environmental and economic domains are raised by many foreign scientists: Lluís Torrent deals with the use of the positive potential of digitalization to improve the environmental situation on Earth (Lluís Torrent. 2020); Flurina Wäspi - the double (positive and risky) impact of digitalization on the environment (Flurina Wäspi. 2021); Sarah Lenz - the scope of digital technologies in solving socio-environmental problems (Sarah Lenz. 2021), and others. At the same time, the mentioned researchers have discussed individual issues of digitalization amidst the economy or ecology without emphasizing the role of legal means in addressing the problems at the national level.

The purpose of the article is to determine the primary effects of digitalization on the eco- logical and economic spheres of public life (both positive, requiring government incentives, and negative, associated with significant risks to the economy and the environment); to analyze research findings on the relevant problems in the contributions of Ukrainian and foreign researchers and the state of legal regulation of public relations in the mentioned areas; to identify problems that need to be addressed to reduce the adverse impact of digitalization risks on the environment and the economy; to develop proposals for solving the identified problems using legal means.

This study relies on general and special methods of scientific cognition, namely: the dialectical method helped expand the essence and purpose of digitalization and trace its economic and environmental impact; formal logic allowed identifying those areas of environmental and economic relations that are characterized by digitalization risks; analysis was used in examining research findings of both domestic and foreign authors, the state of legal regulation of digitalization in the mentioned areas; synthesis made it possible to conclude about common tasks of the state environmental and economic policy; prognostics was applied to determine the potential consequences of uncontrolled digitalization in the relevant areas and develop proposals for the introduction of legal mechanisms to prevent/mitigate its negative effects.

2. The dual impact of digitalization on the environment and the economy

Digital technologies are universal - it is confirmed by the option of applying them in all fields of public life (including environmental protection and the economy). It allows the introduction of more cost-effective and green technologies in production (industrial, construction, agricultural, etc.), solving problems of a search for the most optimal ways of sustainable development of the country and regions to find effective means of addressing current challenges (including the reduction of environmental pollution and increase in the share of environmentally friendly industries). However, the consequences of the use of digital technologies are different: both socially useful/positive and very challenging. These technologies are neither good nor bad (Tepskott Don, Tepskott Aleks. 2019 , p. 30), and the impact (positive or negative) depends on the purpose of their use, good faith and competence of users, and the level of knowledge of the consequences of the use of technologies.

Being very important to society, the economic and environmental spheres have many critical issues to be addressed, including climate change caused by environmental pollution and the need to reduce the negative implica- 
tions of this already irreversible process (OON. 2021) through appropriate measures, which require large-scale investments, reorientation of production to be eco-friendly along with the use of the capacity of digital technologies, incl. artificial intelligence.

Although scientists have discussed the complex impact of digitalization on the environment and the economy, they usually cover each area separately. As a rule, statutory regulation concerns relations in environmental protection and economic management separately. However, there are exceptions: the connection of all these areas and processes can be noticed in the provisions of one of the new laws adopted in recent years - "On the Basic Principles (Strategy) of State Environmental Policy of Ukraine until 2030" (The Law of Ukraine dated 28.02.2019). Among the root causes of environmental problems in Ukraine, it recognizes the functioning of the economic realm with its focus on profitability, often ignoring environmental issues (subordination of environmental priorities to economic feasibility), and disregard for environmental effects of economic activity (including electronic communications) in legislation and statutory acts, weak efficiency of administration in environmental protection and regulation of the use of natural resources, a low level of understanding of environmental priorities and benefits of balanced (sustainable) development in society, imperfection and thus, unsatisfactory level of compliance with environmental legislation and environmental rights and responsibilities of citizens. According to the Law, key objectives of environmental protection embrace the need to ensure the integration of environmental policy in the decision-making process on socio-economic development, including the introduction of e-government technologies in the environmental sphere and automated information systems of environmental data, which will double down on transparency, efficiency and quality of management decisions, observance of environmental rights of citizens.

3. Carbon footprint and other adverse effects of digitalization

Kateryna Markevych in her article "The Carbon Footprint of Digitalization" makes a thorough analysis of the effects of digitalization on the environment, drawing attention to their impact on the economy and the environment - both positive and challenging enough (Markevych K. 2021). K. Markevych attributes the following to the former (advantages of digitalization): effectively designed and managed digital infrastructure that can promote environmental sustainability and reduction of greenhouse gas emissions (thanks to IoT technology and artificial intelligence); water saving and the detection of its contamination; optimization of waste disposal; optimization of energy distribution and consumption in the energy sector and reduction of energy consumption in the manufacturing sector, and $\mathrm{CO}_{2}$ reduction in industrial systems, as well as the improvement of the quality of manufactured products. "Today, as K. Markevych states, there is a lot of practical evidence of the effectiveness of digital technologies, incl. in terms of the transition to sustainable development ... The world can accelerate the transition to a low-carbon economy using digital technologies through standardization, monitoring, and increasing accountability for energy consumption".

However, the impact of digitalization is ambiguous: "digital technologies can both neutralize carbon footprint and generate a particular volume of emissions" because the energy intensity of the digital industry is growing every year, as well as the share of digital technologies in global $\mathrm{CO}$ emissions ${ }_{2}$; the digitalization of the transport sector (increasing energy consumption and global emissions) has the same effect. Thus, digitalization leads to a considerable increase in energy consumption, taking into account not only the use but also the production of digital devices. By driving up global electricity demand, digitalization concurrently generates $\mathrm{CO}_{2}$ (Markevych K. 2021). Another example of the adverse impact of digitalization is the effects of cryptocurrency mining (not only significant consumption of electricity, which increases the carbon footprint and poses a potential threat of electricity shortages to other - domestic, industrial, transport, etc. - needs, and generates a sizeable portion of the heat, which negatively affects the environment (Oberhaus D. 2018).

Summing up the findings of her research, K. Markevych notes that "without decisive political actions, the digital revolution can rise energy consumption and accelerate environmental damage. Therefore, the maintenance of digitalization sustainably is a political priority, which should go hand in hand with the development of levers of control over the digital environmental impact, tools for assessing digital technologies and the consequences of their operation" (Markevych K. 2021).

4. The degree of the legislator's consideration of the adverse effects of digitalization

Valid conclusions of the abovementioned author about ways of reducing the environmental threats of digitalization require the analysis of the relevant current regulations, the consequences of which are as follows:

recognition in some statutory acts (in particular, in the Law "On Basic Principles (Strategy) of State Environmental Policy of Ukraine 
until 2030") of environmental risks of digitalization, as well as of the business activity aimed at increasing profitability through avoiding the costs of green production technologies and, accordingly, ignoring the need to consider the environmental component when deciding on socio-economic development of the country/ regions and taking environmental measures in the process of economic activity;

key statutory acts governing relations in relevant areas (the Commercial Code of Ukraine in the economy, and the Law "On Environmental Protection” dated June 25, 1991 in ecology) lack provisions on state policy aimed at ensuring the social focus of digitalization with appropriate promotion of its socially positive results and prevention / minimization of digitalization-related risks;

a lack of legal mechanisms which can prevent and/or compensate for the adverse impact of digitalization on the environment, i.e., technical regulation, tax policy, enhancement of socially responsible digital entrepreneurship.

\section{5 . Regulation of digital relations}

State intervention in the digitalization domain no longer raises objections, but the calls for the freedom of cyberspace (A Declaration of the Independence of Cyberspace. 1996) and exclusive self-regulation are a thing of the past. The above was driven by the conduct of key players in digitalized markets with their unprecedented incomes amidst the analog economy, stellar ambitions, abuse of digital opportunities, and neglect of environmental and economic issues. The striving of digital, including cryptocurrency, billionaires to explore space using digital technologies, fleeing from environmental problems on Earth (Cockburn H. 2021) is hardly evidence of concern for the welfare of Earth's civilization, because vast sums of money are not applied to the salvation of the Earth, its ecology, but the salvation of the elite (not so much intellectual as monetary). In this context, the issue of using digitalization to solve environmental and economic problems on Earth, not in space, has become crucial. It requires the participation of the entire international community and each state to determine at the legislative level and ensure the practical implementation of measures for orienting all branches of industry on green technologies, outreach, and promotion of socially responsible (in part the environment and mitigation of the risks of digital technologies) business. In digitalization, domestic environmental and economic policy, which is unfortunately ignored by the Commercial Code of Ukraine, holds pride of place in addressing the quite serious problem. In fact, under present-day conditions of society's development, the problems of all its spheres are intertwined and need a comprehensive solution. Thus, the fight against Covid-19 is a challenge to the medical sector and the economy (production of drugs, vaccines, medical equipment and facilities, online provision of various services, financial losses caused by quarantine lockdown because of tight restrictions for running a business), and environmental protection (mass use of personal protective equipment against Covid-19 without proper measures for their disposal causes environmental pollution). This also concerns digitalization which is still accompanied by euphoria about its enormous potential despite the presence of significant risks. As it always has been, today's economic benefits come to the fore, and the problem of threats remains secondary.

\section{Conclusions}

The impact of a market economy and digitalization on the environment is ambiguous. One of the primary causes of environmental pollution is a focus on marginal benefits from business activities, incl. through neglecting green production technologies to reduce production costs. At the same time, digital technologies developed in the process of innovation activity allow controlling the environmental condition, preventing, and reducing its pollution. However, digitalization, despite its great potential for solving complex problems, is associated with considerable risks that can adversely affect the economy and the environment.

The duality of the impact of economic activity (industrial, agricultural, construction) and digitalization on the environment is a problem that must be addressed by a set of measures, especially legal ones. This task should become one of the priority areas of state legal policy (at the national level) with the relevant reflection in the Constitution of Ukraine (in terms of the state's social and environmentally safe focus of digitalization in the economy and other spheres of social life; specification of fundamental digital rights and obligations of citizens), Commercial and other codes/laws (in terms of the consolidation of the specifics of the legal regulation of digital relations in relevant areas of the economy, environmental protection, etc.). In the Commercial Code of Ukraine, it is expedient to define features of the state economic and legal policy in the context of growing threats to public welfare (first of all, in view of climate change caused by pollution) and digitalization that advantages of the latter will not be crossed by its risks, and a socially responsible digital enterprise will be encouraged in a country with a developed digital economy (Ukrayins'kyy instytut maybutn'oho. 2020). 


\section{References:}

A Declaration of the Independence of Cyberspace (1996). URL : http://lab314.brsu.by/kmplite/kmp2/Net/Declaration/declaration.htm (дата звернення: 06.06.2021) (in English).

Analitychnyy zvit (2021). Antykoruptsiynyy ta sotsial'nyy vplyv vidkrytykh derzhavnykh danykh v ekolohichniy sferi Ukrayiny. Berezen' 2021. Zvit pidhotovlenyy hromads'koyu spilkoyu «Tsentr rozvytku innovatsiy» u mezhakh USAID/UK aidproyektu «Prozorist' ta pidzvitnist' u derzhavnomu upravlinni ta posluhakh/TAPAS», shcho realizuyet'sya Fondom Yevraziya, ta za spryyannya Ministerstva tsyfrovoyi transformatsiyi Ukrayiny (Anti-corruption and social impact of open state data in the environmental sphere of Ukraine. Analytical report. March 2021. The report was prepared by the Center for Innovation Development within the USAID / UK aid project "Transparency and Accountability in Public Administration and Services / TAPAS", implemented by the Eurasia Foundation, and with the assistance of the Ministry of Digital Transformation of Ukraine). 62 s. URL : https://tapas.org.ua/wp-content/uploads/2021/03/Ecology-ODStudy-Impact-.pdf (in Ukrainian).

Beck Ulrich. (1992). RISK SOCIETY. Towards a New Modernity. Translated by Mark Ritter SAGE. Publications London • Newbury Park • New Delhi. 1992. P.263. URL http://www.riversimulator.org/Resources/Anthropology/RiskSociety/RiskSocietyTowardsAnewModernity1992Beck.pdf (in English).

Cockburn, H. (2021). Can we really move heavy industry to space to solve the climate crisis, as Jeff Bezos has suggested? 2021. Available at: https://www.independent.co.uk/climate-change/ news/bezos-space-heavy-industry-pollution-b1888147.html (in English).

Het'man, A.P., Atamanova, Yu.Ye., Milash, V. S. ta in. (2016). Pravove rehulyuvannya vidnosyn u merezhi Internet : monohrafiya / [za red. S. V. Hlibka, K. V. Yefremovoyi] (Legal regulation of relations on the Internet: a monograph / [A. P. Hetman, YE Atamanova, VS Milash and others]; for order. SV Glebko, KV Efremova). - Kharkiv : Pravo, 2016. 360 s. (in Ukrainian).

Kinakh Marharyta. (2020). Zelenyy kurs Ukrayiny: yak derzhava ta biznes otsinyuyut' ekolohichnu polityku (Ukraine's Green Course: How the State and Business Assess Environmental Policy). Yurydychna hazeta onlayn. 11 lystopada 2020 r. URL : https://yur-gazeta.com/ golovna/zeleniy-kurs-ukrayini-yak-de rzhava-ta-biznes-ocinyuyut-ekologichnu-politiku.html (in Ukrainian).

Lenz Sarah. (2021). Is digitalization a problem solver or a fire accelerator? Situating digital technologies in sustainability discourses // Social Science Information. Vol. 60(2). 188-20 (in English).

Malysheva, N.R. (2021). Kiberbezpeka kosmichnoyi diyal'nosti ta mozhlyvosti yiyi zabezpechennya zasobamy mizhnarodnoho prava (Cybersecurity of space activities and the possibility of its provision by means of international law). DOI: 10.33663/0869-2491-2021-32-245-257. Pravova derzhava. Shchorichnyk naukovykh prats'. Vyp. 32. Kyyiv: In-t derzhavy i prava imeni V. M. Korets'koho NAN Ukrayiny, 2021. P. 245-257(in Ukrainian).

Markevych Kateryna. (2021). Vuhletsevyy slid tsyfrovizatsiyi (Carbon trace of digitalization). URL : https://razumkov.org.ua/statti/vugletsevyi-slid-tsyfrovizatsii (in Ukrainian).

Oberhaus, D. (2018). Bitcoin Mining Alone Could Raise Global Temperatures Above Critical Limit by 2033. URL : https://www.vice.com/en/article/neganb/bitcoin-mining-could-raise-globaltemperatures-by-2-c (in English).

OON: Zminy klimatu masshtabnishi, nizh prypuskaly (UN: Climate change is bigger than previously thought). (2021). URL : https://www.epravda.com.ua/news/2021/09/17/677910/ (in Ukrainian).

Romanko, S. (2019). Ekoloho-pravova polityka Ukrayiny u sferi zminy klimatu (Environmental and legal policy of Ukraine in the field of climate change). Pidpryyemnytstvo, hospodarstvo i pravo, №9. S. 88-94. DOI https://doi.org/10.32849/2663-5313/2019.9.15 (in Ukrainian).

Tepskott Don, Tepskott Aleks. (2019). Blokcheyn revolyutsiya. Yak tekhnolohiya, shcho lezhyt' v osnovi bitkoyina ta inshykh krypto valyut, zminyuye svit. Perz z anhl.. YU.Hryhorenko ta H.Leviv (Blockchain Revolution. How the Technology Behind Bitcoin and Other Criptocurrencies is Changing the World). L'viv : Litopys, 2019. 492 s. (in Ukrainian).

Torrent Lluís (2020). Ecological transition and digitalisation, an essential alliance in the climate decade. URL : https://www.telefonica.com/en/web/public-policy/blog/article/-/blogs/ecological-transition-and-digitalisationan-essential-alliance-in-the-climate-decade (in English)

Tsentr Razumkova. (2020). Tsyfrova ekonomika: trendy, ryzyky ta sotsial'ni determinanty (Digital economy: trends, risks and social determinants). Kyyiv, zhovten' 2020 r. Vydavnytstvo "Zapovit", 2020. 274 s.URL :https://razumkov.org.ua/uploaarticle/2020_digitalizationds/pdf (in Ukrainian). 
Vinnyk Oksana M., Shapovalova Olga V., Patsuriia Nino B., Honcharenko Olena M., Yefremova Kateryna V. (2020). The problem of ensuring the social direction of the legislation of Ukraine on the digital economy. Asia Life Sciences. Issue 1, July, 133-151 (in English).

Vinnyk Oksana M., Zadykhaylo Dmytro V., Honcharenko Olena M., Shapovalova Olga V., Patsuriia Nino B. (2021). Economic and Legal Policy of the State in the Field of Digital Economy. International Journal of Criminology and Sociology, 2021, 10, 383-392 (in English).

Ukrayins'kyy instytut maybutn'oho. (2020). Ukrayina 2030E - krayina z rozvynutoyu tsyfrovoyu ekonomikoyu (Ukraine 2030E - a country with a developed digital economy). URL: https://strategy.uifuture.org/kraina-z-rozvinutoyu-cifrovoyu-ekonomikoyu. html\#6-2-1 (in Ukrainian).

Wäspi Flurina (2021). Digitization and the Environment: Opportunities, Risks and the Need for-action. - SocietyByte. URL : https://www.societybyte.swiss/en/2020/04/09/digitization-and-the-environment-opportunities-risks-and-the-need-for-action/ (in English)

\section{Оксана Вінник,}

доктор юридичних наук, професор, илен-кореспондент Національної академї правових наук України, головний науковий співробітник відділу міжнародного приватного права та правових проблем євроінтеграції, Науково-дослідний інститут приватного права і підприємництва імені академіка Ф. Г. Бурчака Національної академії правових наук України, вул. Раєвського, 23 а, Киї, Україна, індекс 01042, оvinnyk@ukr.net

ORCID: orcid.org/0000-0002-9397-5127

Scopus-Author ID: 57217737384

\section{ЕКОЛОГІЧНИЙ СКЛАДНИК В ЕКОНОМІКО-ПРАВОВІЙ ПОЛІТИЦІ ДЕРЖАВИ}

Анотація. Мета. У сучасну епоху розвитку суспільства, яку вже називають цифровою з огляду на широке використання цифрових технологій, вплив останніх на екологію є неоднозначним: крім позитивного ефекту (наприклад, можливість вирішення надскладних завдань), цифровізація пов'язана зі значними ризиками. У статті досліджується низка проблем цифровізації (з позиції іiі впливу на сфери економіки й екологіï) з метою напрацювання правових засобів зменшення пов'язаних із цим процесом ризиків.

Методи дослідження. Використання наукових методів дослідження (діалектичного, формально-логічного, системного аналізу, синтезу, синергетичного, прогностичного та інших методів) дало змогу зробити висновок про необхідність коригування економіко-правової політики держави в сучасних умовах цифровізації з обов'язковим урахуванням екологічного складника.

Результати. Висновок про необхідність урахування на рівні законодавства не лише позитивних, а й негативних наслідків впливу цифровізації грунтується на аналізі фактичного стану справ в економічній та екологічних сферах, теоретичних праць українських і зарубіжних авторів, а також стану нормативно-правового регулювання зазначених відносин. У результаті проведеного дослідження виявлено неоднозначність наслідків застосування цифрових технологій, використання яких може бути досить сприятливим для суспільства, проте пов'язується з істотними ризиками. Ідеться, зокрема, про застосування цифрових технологій без урахування екологічного складника (так званого вуглецевого сліду, що прискорює негативні зміни клімату) безвідносно до ймовірності настання інших негативних наслідків.

Висновки. Підсумком проведеного дослідження є виявлення комплексу проблем, пов’язаних із впливом цифровізації на економіку та екологію, встановлення взаємозв'язку цих проблем, а також незадовільного стану їх вирішення за допомогою правових засобів; надання пропозицій щодо вдосконалення правового забезпечення розв'язання проблем ризикового впливу цифровізації на економіку й екологію, а саме включення в основні акти законодавства, що регулюють відносини в зазначених сферах (Конституцію України, Господарський кодекс України та Закон України «Про охорону навколишнього природного середовища»), положень щодо забезпечення державою соціального спрямування цифровізації, що включає стимулювання позитивного використання цифрових технологій і мінімізацію пов'язаних із цифровізацією ризиків.

Ключові слова: економіка, екологія, цифровізація, ризики цифровізації, удосконалення законодавства. 